\title{
Nicotinic Receptor Contributions to Smoking: Insights from Human Studies and Animal Models
}

\author{
Darlene H. Brunzell • Alexandra M. Stafford • \\ Claire I. Dixon
}

Published online: 19 February 2015

(C) Springer International Publishing AG 2015

\begin{abstract}
It is becoming increasingly evident that a variety of factors contribute to smoking behavior. Nicotine is a constituent of tobacco smoke that exerts its psychoactive effects via binding to nicotinic acetylcholine receptors (nAChRs) in brain. Human genetic studies have identified polymorphisms in $\mathrm{nAChR}$ genes, which predict vulnerability to risk for tobacco dependence. In vitro studies and animal models have identified the functional relevance of specific polymorphisms. Together with animal behavioral models, which parse behaviors believed to contribute to tobacco use in humans, these studies demonstrate that nicotine action at a diversity of nAChRs is important for expression of independent behavioral phenotypes, which support smoking behavior.
\end{abstract}

Keywords Tobacco $\cdot$ Nicotine $\cdot$ Addiction $\cdot$ Acetylcholine . Cholinergic $\cdot$ e-cigarettes

\section{Nicotinic Acetylcholine Receptors}

The primary addictive component identified in tobacco smoke is nicotine, which exerts its behavioral effects via interaction with nicotinic acetylcholine receptors (nAChRs). Broadly, nAChRs can be separated into two main categories: neuronal

\footnotetext{
This article is part of the Topical Collection on Tobacco

D. H. Brunzell $(\triangle) \cdot$ A. M. Stafford · C. I. Dixon

Department of Pharmacology and Toxicology,

Virginia Commonwealth University, Blackwell Smith Building,

410 N. 12th St., Richmond, VA 23298, USA

e-mail: dbrunzell@vcu.edu

A. M. Stafford

e-mail: staffordam2@vcu.edu

C. I. Dixon

e-mail: cidixon@vcu.edu
}

and muscle receptors. Muscle and neuronal $\mathrm{nAChRs}$ are pentameric transmembrane cation channels belonging to the superfamily of ligand-gated ion channels that include the GABA, 5-HT, and glycine receptors, but a different complement of subunits makes muscle and neuronal $\mathrm{nAChRs}$ responsive to different compounds. Muscle nAChRs consist of $\alpha 1$, $\beta 1, \gamma, \delta$, and $\varepsilon$ subunits, whereas neuronal nAChRs consist of $\alpha 2-10$ and $\beta 2-4$ (for a more detailed review of nAChR composition and function, see [1]). As most nicotine-associated behaviors are thought to be regulated in the CNS, neuronal nAChRs in the periphery would not make ideal drug targets.

The composition of the receptor and neuroanatomical localization adds to the specificity and complexity of cholinergic signaling by conveying differing pharmacologic characteristics. Heteromeric nAChRs $\left(\beta 2 *\right.$ and $\beta 4^{*}$; *denotes assembly with other subunits) are generally more sensitive to agonists, with some subtypes of $\beta 2{ }^{*} \mathrm{nAChRs}$ demonstrating functional activity at nanomolar concentrations, whereas homomeric nAChRs $(\alpha 7, \alpha 9$, and $\alpha 10)$ generally require micromolar concentrations of agonist for their activation [1]. Following activation, nAChRs enter a desensitized (inactive) state and some heteromeric receptors show preferential desensitization at low concentrations of nicotine. As described below, diverse behavioral outcomes appear to be achieved by activation versus inhibition of nAChRs.

$n A C h R s$ are expressed in brain areas that regulate a variety of behaviors. $\beta 2 * n A C h R s$ (including two major subclasses $\alpha 4 \beta 2 *_{\text {- }}$ and $\alpha 6 \beta 2 *_{\mathrm{n} A C h R s)}$ and $\alpha 7 \mathrm{nAChRs}$ are the most common nAChR subtypes in the CNS with complementary expression in the dorsal striatum, thalamus, and amygdala but with neuroanatomical overlap in the ventral tegmental area (VTA), cortex, hippocampus, and basal ganglia [2-4]. These brain areas regulate sensory transmission, learning and memory, emotion, and reward. The $\alpha 6 \beta 2{ }^{*} \mathrm{nAChRs}$ are selectively expressed in catecholaminergic nuclei and enriched in the mesolimbic DA system, which is believed to support 
addictive drugs. $\alpha 3 \beta 4^{*}$ nAChRs have modest CNS expression but are enriched in the medial habenula $(\mathrm{mHb})$ to interpeduncular nucleus (IPN) pathway with a small subset of these receptors containing the $\alpha 5$, i.e., $\alpha 3 \alpha 5 \beta 4$ [5-7]. The mHb-IPN pathway regulates the mesolimbic system and is highly implicated in smoking phenotype. $\alpha 3$ and $\beta 4$ nAChR subunits also form nAChRs in the ganglion, however, raising considerations about possible peripheral autonomic side effects that could result from drug targeting of $\alpha 3 \beta 4 *$ nAChRs. A small population of $\alpha 3 \beta 2 * n A C h R s$ in the habenula and IPN may prove important for smoking phenotype, but there are currently limited tools to assess this.

\section{nAChR Contributions to Smoking}

\section{$\beta 2 *_{\text {nAChRs }}$}

Although genome-wide association studies (GWAS) have failed to yield convincing evidence for $\beta 2$ subunit polymorphisms that predict risk for tobacco dependence, candidate gene studies further show that polymorphisms in CHRNB2 are associated with the subjective effects of nicotine, Fagerstrōm Test for Nicotine Dependence (FTND) scores [8]; and varenicline, bupropion, and nicotine replacement therapy outcomes [9-11, 12, 13, 14]. Furthermore, GWAS, linkage analysis and candidate gene studies have greatly implicated CHRNA3, CHRNA4, CHRNA5, CHRNA6, and CHRNB3 $[15,16 \bullet, 17 \bullet, 18 \bullet 19-22]$ nAChR subunit genes that assemble with $\beta 2$ to make functional receptors (see Table 1). Of these, $\alpha 4$ (CHRNA4) and $\alpha 6$ (CHRNA6) primarily assemble with $\beta 2$ in brain areas thought to regulate nicotine/ tobacco reinforcement.

CHRNA4 and CHRNA6 variations are linked to tobacco dependence. Numerous studies assessing nicotine dependence demonstrate that multiple CHRNA4 polymorphisms, especially rs2236196, rs1044394, and rs1044396, are associated with increased FTND score, DSM-IV nicotine dependence symptoms, and cigarettes per day (CPD) [15, 20, 29-33]. Increased sensitivity to the subjective effects of nicotine and better cessation outcomes have also been associated with these CHRNA4 variants [13, 34]. Linkage analysis among a population of nicotine-dependent or non-dependent individuals reveals that rare CHRNA4 variants are protective against nicotine dependence. In addition, this study revealed that these variants are associated with altered $\beta 2 * n A C h R$ binding in the brain, as measured by SPECT imaging [35]. In vitro data indicate that these rare variants result in both increased expression and function of $\alpha 4 \beta 2 *$ nAChRs [36]. Although less studied than CHRNA4, recent evidence also implicates CHRNA6 polymorphisms in smoking behaviors and dependence. Risk for nicotine dependence has been associated with polymorphisms in CHRNA6, especially rs13277254, located upstream of the CHRNA6-CHRNB3 gene cluster [15, 28, 29, 31, 37-40]. A few studies have shown that variation in CHRN A6 is positively associated with smoking initiation, initial sensitivity, and positive subjective effects of nicotine that predict susceptibility to smoking [38, 41]. Furthermore, varenicline, a partial agonist of $\alpha 4 \beta 2 * n A C h R s$ (including $\alpha 4 \alpha 6 \beta 2 * \mathrm{nAChRs}$ ) is highly effective for promoting smoking cessation $[42,43]$ and reducing craving, withdrawal and pleasurable experiences associated with smoking [44-46] (but see discussion of varenicline agonist properties at $\alpha 7 \mathrm{nAChRs}$ below).

Imaging studies using a highly selective $\beta 2 * n A C h R$ competitive agonist, 5-iodo-A85830, demonstrate that the smoke from a single cigarette results in nicotine binding of more than $88 \%$ of the $\beta 2 *$ nAChRs in brains of smokers [47•]. Not only do $\beta 2 *$ nAChRs appear to be highly relevant for smoking, nicotine/tobacco exposure also increases expression or function of these nAChRs [48]. Post mortem and imaging studies demonstrate that $\beta 2 *_{n} \mathrm{AChR}$ binding is increased in human smokers, suggesting nicotine-induced upregulation of these receptors with receptor levels requiring weeks to return to levels observed in non-smokers [49-53]. Decreased $\alpha 4 \beta 2 *$ nAChR density in brains of smokers has also been associated with better cessation outcomes [54], further suggesting that $\beta 2 * n A C h R s$ support tobacco dependence.

$\alpha 3^{*}, \alpha 5^{*}, \beta 4^{*}$ nAChRs

CHRNA3-CHRNA5-CHRNB4 genes, closely clustered on chromosome 15 , encode the $\alpha 3, \alpha 5$, and $\beta 4$ subunits of the $\mathrm{nAChR}$ and are often co-expressed and co-regulated. Initial GWAS have identified SNPs within this region as being associated with nicotine dependence $[15,16 \bullet, 17 \bullet, 18 \bullet]$. Further candidate gene studies and meta-analyses have identified CHRNA3-CHRNA5-CHRNB4 SNPs associated with dependence [25-27], smoking initiation [23, 55, 56], and heavy smoking behavior $[28,57]$. The most common SNPs identified are rs16969968 of CHRNA5 and rs578776 in CHRNA3 $[15,18 \bullet, 26-29,55]$. These particular SNPs are not in linkage disequilibrium and so appear to represent two independent gene clusters, producing haplotypes with distinct associations to nicotine dependence. The minor A allele of rs16969968 is considered a "risk" allele due to high frequency in the smoking population, whereas the minor $\mathrm{G}$ allele of rs578776 is expressed less frequently and thus considered to be protective [15]. Therefore, a combination of the rs 16969968 A allele and rs578776 C allele is considered the haplotype with the most risk for nicotine dependence, with the opposite alleles conveying a protective effect.

Polymorphisms of the CHRNA3-CHRNA5-CHRNB4 cluster are known to have functional effects. The most commonly associated SNP of the CHRNA5 gene, rs16969968, results in a non-synonymous substitution of aspartic acid to 
Table 1 Human genetics data linking nicotinic receptor genes to smoking

\begin{tabular}{|c|c|c|c|}
\hline Gene & SNP & Phenotype & References \\
\hline \multirow[t]{4}{*}{ CHRNB2 } & rs2072658 & $\begin{array}{l}\text { Increased early subjective response } \\
\text { to tobacco (negative physical; positive) }\end{array}$ & Ehringer et al. [9]; Hoft et al. [13] \\
\hline & rs2072660 & Increased FTND score (minor allele) & Wessel et al. 12] \\
\hline & $\begin{array}{l}\text { rs2072661 } \\
\text { rs3811450 }\end{array}$ & $\begin{array}{l}\text { Decreased abstinence rates (minor allele); } \\
\text { increased withdrawal symptoms } \\
\text { (minor allele) }\end{array}$ & Conti et al. [10]; Perkins et al. [11] \\
\hline & rs4262952 & $\begin{array}{l}\text { Increased odds of continuous abstinence } \\
\text { with varenicline }\end{array}$ & King et al. [14] \\
\hline CHRNB4 & rs 1948 & $\begin{array}{l}\text { Earlier age of smoking initiation (risk } \\
\text { allele: } \mathrm{CC} \text { ) }\end{array}$ & Schlaepfer et al. [23] \\
\hline \multirow[t]{4}{*}{ CHRNA3 } & rs578776 & $\begin{array}{l}\text { Increased FTND score (risk allele: G); } \\
\text { positive smoking status }\end{array}$ & Saccone et al. [15]; Hong et al. [24] \\
\hline & rs6495308 & Increased CPD (risk allele: T) & Berrettini et al. [16•]; \\
\hline & rs 1051730 & $\begin{array}{l}\text { Increased FTND score (minor allele); } \\
\text { increased CPD; elevated cotinine } \\
\text { levels; positive smoking status }\end{array}$ & $\begin{array}{l}\text { Thorgeisson et al. [17•]; Keskitalo et al. [25]; } \\
\text { Chen et al. [26]; Hong et al. [24]; Munafo } \\
\text { et al. [27] }\end{array}$ \\
\hline & rs3743078 & Increased CPD (risk allele: CC) & Stevens et al. [28] \\
\hline \multirow[t]{5}{*}{ CHRNA4 } & rs2229959 & $\begin{array}{l}\text { Increased early subjective response to } \\
\text { tobacco (negative physical) }\end{array}$ & Hoft et al. [13] \\
\hline & rs2236196 & $\begin{array}{l}\text { Increased FTND score; increased CPD; } \\
\text { increased heaviness of smoking; rush/ } \\
\text { high; cognitive effects; abstinence rates }\end{array}$ & $\begin{array}{l}\text { Saccone et al. [29, 15]; Li et al. [20]; } \\
\text { Hutchison et al. [34] }\end{array}$ \\
\hline & rs2273504 & $\begin{array}{l}\text { Increased FTND score; increased CPD; } \\
\text { increased heaviness of smoking }\end{array}$ & Li et al. [20]; Saccone et al. [15] \\
\hline & rs1044394 & $\begin{array}{l}\text { Increased FTND score; increased DSM-IV } \\
\text { dependence symptoms }\end{array}$ & Han et al. [32]; Kamens et al. [33] \\
\hline & rs1044396 & $\begin{array}{l}\text { Increased/decreased FTND score; smoking } \\
\text { quantity; heaviness of smoking; DSM-IV }\end{array}$ & $\begin{array}{l}\text { Feng et al. [19]; Li et al. [20]; Han et al. [32]; } \\
\text { Kamens et al. [33] }\end{array}$ \\
\hline
\end{tabular}

rs1044397

rs 3787137

rs3746372

rs6122429

CHRNA5

rs16969968

rs514743

rs55853698

CHRNA6

rs13277254

rs 2304297

rs7828365

rs9298628

rs 2217732

rs 13273442

rs892413

CHRNA7

rs904952

rs10438287

dependence symptoms; cigarettes per day

Decreased FTND score

Increased FTND score; increased CPD; increased heaviness of smoking

Increased CPD

Increased self reports of nicotine reward

Increased FTND score (risk allele: A); increased $\mathrm{CPD}$; increased heaviness of smoking (risk allele A); increased risk of habitual smoking; elevated cotinine levels; increased subjective pleasure in early smoking; positive smoking status

Earlier age of smoking initiation (risk allele: TT)

Significant association with CPD

Increased FTND score; increased DSM-IV dependence symptoms; increased CPD; earlier age of smoking initiation

Increased FTND score; significant association with DSM-IV dependence symptoms; positive subjective response to nicotine Increased heaviness of smoking

Increased FTND score

Increased FTND score; increased CPD

Significant association with FTND score; increased FTND score
Feng et al. [19]

Li et al. [20]

Voineskos et al. [30]

Hutchison et al. [34]

Saccone et al. [29]; Bierut et al. [18]; Sherva et al. [55]; Stevens et al. [28]; Chen et al. [26]; Saccone et al. [15]; Grucza et al. [56]; Hong et al. [24]; Munafo et al. [27]

Schlaepfer at al. [23]

Liu et al. [57]

Saccone et al. [15, 31]; Hoft et al. [37]; Thorgeirsson et al. [38]

Saccone et al. [29]; Hoft et al. [37]; Zeiger et al. [41]

Stevens et al. [28]

Wang et al. [39]; Culverhouse et al. [40]

Wang et al. [39]

Greenbaum et al. [62]; Philibert et al. [63]; Saccone et al. [31] 
Table 1 (continued)

\begin{tabular}{lll}
\hline Gene & PNP & References \\
\hline & rs12915265 & \\
rs6494212 & \\
rs904951 & \\
rs1913456 & Increased dizziness at first inhalation & \\
rs7178176 & Pedneault et al. [65] \\
\hline
\end{tabular}

Abbreviations: Fagerström Test of Nicotine Dependence (FTND); cigarettes per day (CPD)

asparagine at position 398 (D398N) [18•, 29]. This substitution causes decreased ACh-evoked function at $\alpha 5^{*} \mathrm{nAChRs}$ without altering expression in cultured cells $[18 \bullet, 58]$. fMRI studies have shown a reduced anterior cingulate cortex (ACC) to NAc connectivity in human subjects expressing the D398N substitution [24], which is associated with addiction severity. In mice, this substitution results in a partial loss of receptor function, with increased nicotine intake and decreased sensitivity to the rewarding properties of nicotine [59, 60]. These data suggest that the risk allele of the rs16969968 in the CHRNA5 gene decreases sensitivity to nicotine and increases the propensity for addiction. The risk allele of rs578776 within CHRNA3, however, lowers activation of the ACC [61] and decreases function of the ACC to thalamus pathway [24]. This reduced function is thought to be associated with feedback information about reward rather than anticipation and is more strongly associated with recent nicotine exposure than addiction severity. These studies implicate a role for $\alpha 5^{*} \mathrm{nAChRs}$ in mediating the rewarding effects of nicotine, whereas $\alpha 3{ }^{*} \mathrm{nAChRs}$ appear to mediate feedback information about nicotine exposure, suggesting that the $\alpha 3 \mathrm{nAChR}$ subunit may be more involved in craving or withdrawal processes.

$\alpha 7^{*}$ nAChRs

Polymorphisms within the CHRNA7 gene encoding the $\alpha 7$ $\mathrm{nAChR}$ have been linked to smoking behavior in different populations but with varying results. SNPs of the CHRNA7 gene have been associated with nicotine dependence in women [62], whereas adoption studies found that a link was evident in male subjects but not females [63]. Likewise, a CHRN A7 and nicotine dependence relationship has been noted in African American individuals but not European Americans [31], with one study of a UK-based population finding no association [64]. Recent data has associated the CHRNA7 gene with an increased probability of dizziness at first inhalation [65]. Since increased sensitivity at initiation of smoking is positively linked to nicotine dependence [66], this provides some evidence that $\alpha 7 \mathrm{nAChRs}$ may be involved in initiation of smoking in healthy individuals. As mentioned above, varenicline may also promote smoking cessation, in part, via stimulation of $\alpha 7 \mathrm{nAChRs}[1,67 \bullet]$. However, the specific contribution of $\alpha 7 \mathrm{nAChRs}$ to varenicline smoking cessation effects in humans has not currently been elucidated.

The most notable association between the $\alpha 7 \mathrm{nAChRs}$ and smoking occurs in individuals suffering from schizophrenia. It is well established that tobacco use is more prevalent in individuals with schizophrenia diagnosis than in the general population $[68,69]$. Smokers with schizophrenia not only smoke more cigarettes but also tend to extract more nicotine from a cigarette than healthy counterparts [70]. Variations of the CHRNA7 gene have been associated with smoking in this population [71-73]. There is approximately a $50 \%$ reduction in expression of $\alpha 7 *^{*} \mathrm{AChRs}$ found in the brains of subjects with schizophrenia compared to healthy controls [74, 75]; as detailed in the animal model section below, reductions in $\alpha 7 \mathrm{nAChR}$ function may increase nicotine use and reward. One theory for reduced $\alpha 7 \mathrm{nAChR}$ expression is that a truncated duplicate $\alpha 7$ gene acts as a dominant negative to prevent expression of $\alpha 7$ nAChRs at the cellular membrane [76]. A self-medication hypothesis suggests that some individuals with schizophrenia smoke to relieve deficits in appropriate filtering of sensory stimuli $[77,78]$. Polymorphisms at the gene locus for the $\alpha 7 \mathrm{nAChR}$ on chromosome 15 regulate these "P50" sensory deficits [79] and tobacco use counteracts this phenotype [77, 78].

\section{nAChR Contributions to Addiction Phenotype: Animal Models}

Reward and Reinforcement

Rodent studies have highly implicated $\beta 2 * n A C h R s$ in nicotine reward and reinforcement. Knockout mice with a null mutation of the $\beta 2$ subunit $(\beta 2 \mathrm{KO})$ fail to selfadminister nicotine [80•, 81-83], do not show nicotineconditioned place preference (CPP) [84] and do not show nicotine enhancement of conditioned reinforcement [85]. Similarly, local infusion of the $\beta 2 *_{\mathrm{nAChR}}$-selective antagonist, dihydro-beta-erythroidine $(\mathrm{DH} \beta \mathrm{E})$ into the VTA greatly attenuates nicotine self-administration in rats [86•]. $\beta 2 \mathrm{KO}$ mice also fail to show nicotine-stimulated locomotor activation, a behavior, which like nicotine reward and reinforcement 
requires dopamine (DA) release [87]. Not surprisingly, in vitro studies combining genetic and pharmacological tools reveal that activation of $\beta 2 * \mathrm{nAChRs}$ is required for nicotine-induced DAergic neuron firing and NAc DA release $[80 \bullet, 88]$. Behaviorally, re-expression of $\beta 2$ subunit in the mesolimbic DA pathway rescues nicotine-associated locomotor activity and acquisition of nicotine self-administration in $\beta 2 \mathrm{KO}$ mice $[83,89]$, suggesting that $\beta 2 *_{n} \mathrm{AChRs}$ in this pathway are critical and sufficient for nicotine addiction-like phenotype (see Table 2).

$\alpha 4$ and $\alpha 6$ subunits, which require $\beta 2$ for their assembly, are also critical for nicotine reward, reinforcement and nicotine-associated locomotor activation. $\alpha 4 \mathrm{KO}$ mice do not exhibit nicotine CPP, do not self-administer nicotine [83, 91, 92], and exhibit blunted nicotine-stimulated DA release at baseline $[83,91,92,93]$. In addition, $\alpha 4 \beta 2 * n A C h R$ gainof-function mice with a single-point mutation in the $\alpha 4$ subunit (L9A) show leftward shifts in nicotine CPP and associated DAergic neuron firing [94], suggesting that activation of $\alpha 4 *$ nAChRs is sufficient for nicotine reinforcement and reward. Similarly, $\alpha 6 \mathrm{KO}$ mice fail to develop nicotine selfadministration or nicotine CPP and delivery of selective $\alpha 6 \beta 2 *$ nAChR $\alpha$-conotoxin MII antagonists (CTX) into the VTA or NAc blocks nicotine self-administration and CPP, suggesting that activation of mesolimbic $\alpha 6 \beta 2 * \mathrm{nAChRs}$ is critical for nicotine reinforcement and reward [83, 91, 95-98]. Recent ex vivo studies suggest that $\alpha 4 \alpha 6 \beta 2 *$ nAChRs make up a subclass of nAChRs in the VTA which are highly sensitive to physiologically relevant doses of nicotine [99], presumably due to binding at the $\alpha 4-\alpha 6$ interface. $\alpha 6 \beta 2 *$ nAChRs are thought to contribute to as much as $80 \%$ of nicotine-stimulated DA release on NAc terminals [100]. Electrophysiological studies reveal that mice with a gain-of-function single-point mutation of the $\alpha 6$ subunit (L9S) are hypersensitive to endogenous $\mathrm{ACh}$ and nicotine, resulting in enhanced VTA DAergic neuron activity and DA release at terminals in the NAc compared to wild type mice, an effect blocked by CTX [101]. L9S mice show a parallel hyperlocomotor response to nicotine that appears to require the $\alpha 4$ subunit since L9S mice bred to have an $\alpha 4$ null mutation fail to show this phenotype [102].

Other nAChR subunits have also been implicated in nicotine reward and reinforcement. For example, $\alpha 2 \mathrm{KO}$ and $\alpha 5 \mathrm{KO}$ mice display increased nicotine self-administration compared to WT $[103,104]$. When $\alpha 5$ is re-expressed in the $\mathrm{mHb}$, nicotine self-administration returns to WT levels [103]. Mice overexpressing $\beta 4$ show decreases in freely available nicotine intake, an effect that is rescued by $\mathrm{mHb}$ expression of the $\alpha 5$ variant, D398N $[59,60,105]$. These studies suggest that independent $\beta 4^{*}$ - and $\alpha{ }^{*}$ nAChRs work in opposition to regulate nicotine intake or that introduction of the $\alpha 5$ subunit into the $\alpha 3 \beta 4 *$ nAChR not only changes the properties of the receptor, as was discussed above [18•, 58-60], but also has a significant effect on nicotine-dependent behavioral outcomes.

Although early studies suggested that $\alpha 7 \mathrm{nAChRs}$ did not play a critical role in nicotine reinforcement or reward [83, 84], an accumulation of recent data suggest that low affinity $\alpha 7 \mathrm{nAChRs}$ work in opposition to $\beta 2{ }^{*} \mathrm{nAChRs}$, enhancing nicotine reinforcement and reward when $\alpha 7 \mathrm{nAChRs}$ are genetically or pharmacologically inhibited and reducing nicotine self-administration and nicotine CPP when $\alpha 7 \mathrm{nAChRs}$ are stimulated $[106,107]$. Studies assessing methyllycaconitine (MLA), an $\alpha 7 \mathrm{nAChR}$ antagonist, effects on nicotine selfadministration have returned mixed results [108, 109], perhaps because MLA has potency as an $\alpha 6 \beta 2 * n A C h R$ antagonist [110]. Local infusion of a highly selective $\alpha 7$ antagonist peptide, $\alpha$-conotoxin ArIB [V11L, V16D], into the NAc or ACC resulted in a nearly threefold increase in active lever pressing and breakpoints during a progressive ratio schedule of reinforcement suggesting that a loss of $\alpha 7 \mathrm{nAChR}$ function in these brain areas, such as that seen with schizophrenia, increases nicotine self-administration [106]. Nicotineassociated DA release is elevated in $\alpha 7 \mathrm{KO}$ mice [111], which show leftward shifts in nicotine CPP [107] following systemic nicotine injection. By contrast, $\alpha 7 \mathrm{KO}$ mice showed impaired oral nicotine self-administration during a two-bottle choice but only after 40 days of exposure suggesting that $\alpha 7 \mathrm{nAChRs}$ may differentially regulate initiation and maintenance of nicotine self-administration in $\alpha 7 \mathrm{KO}$ mice [83, 112]. Rodent studies using $\alpha 7$-selective agonist compounds, however, show that both nicotine CPP, a subchronic paradigm [107], and nicotine self-administration following more chronic dosing [106] are inhibited when $\alpha 7 \mathrm{nAChRs}$ are stimulated.

\section{Dependence}

Nicotine dependence in rodent studies is characterized by physical and affective signs of withdrawal. This is generally achieved by providing continuous chronic or semi-chronic exposure to nicotine followed by removal of nicotine (spontaneous withdrawal) or by injection of a $\mathrm{nAChR}$ antagonist such as mecamylamine (MEC) (precipitated withdrawal). Physical nicotine withdrawal results in an increase of somatic signs [113-116] (e.g., paw tremor, body shakes, stretching, scratching, piloerection) as well as hyperalgesia [116, 117]. Affective signs of withdrawal include increases in anxiety behavior measured on the elevated plus maze (EPM) and light dark box $[116,118,119]$ and a reduction in reward processing as indicated by increased reward thresholds in the intracranial self stimulation procedure (ICSS) [109, 115, 120-122].

Pharmacological and genetic studies have implicated $\beta 2 *_{n} A C h R s$ in withdrawal behavior. DH $\beta E$-precipitated withdrawal results in somatic signs $[114,116,120]$ and increased anxiety in the EPM [116] following chronic nicotine exposure. It is interesting that administration of the partial 
Table 2 Pharmacological and genetic findings linking nAChR subunits to nicotine addiction phenotype

\begin{tabular}{|c|c|c|c|}
\hline Subunit & Manipulation & Behavioral Outcome & Reference \\
\hline \multirow[t]{24}{*}{$\beta 2$} & \multirow[t]{9}{*}{ KO } & $\begin{array}{l}\text { Nicotine self-administration blocked (rescued by re-expression } \\
\text { in VTA) }\end{array}$ & $\begin{array}{l}\text { Picciotto et al. [80•]; Maskos et al. [81]; } \\
\text { Besson et al. [82]; Pons et al. [83] }\end{array}$ \\
\hline & & $\begin{array}{l}\text { Nicotine CPP blocked (not rescued by low-level re-expression } \\
\text { in VTA) }\end{array}$ & Walters et al. [84]; Mineur et al. [89] \\
\hline & & Conditioned reinforcement blocked & Brunzell et al. [85] \\
\hline & & $\begin{array}{l}\text { Nicotine locomotor activation blocked (rescued by low-level } \\
\text { re-expression in VTA) }\end{array}$ & King et al. [87], Mineur et al. [89] \\
\hline & & Nicotine evoked DA release blocked & Zhou et al. [88] \\
\hline & & Loss of nicotine-stimulated DAergic neuron firing & Picciotto et al. $[80 \bullet]$ \\
\hline & & Loss of anxiety-related behavior (EPM) & Jackson et al. [119] \\
\hline & & Loss of withdrawal-induced increases in anxiety (EPM) & Jackson et al. [119] \\
\hline & & Withdrawal-induced increases in somatic signs intact & Salas et al. [117]; Jackson et al. [119] \\
\hline & \multirow[t]{8}{*}{$\mathrm{DH} \beta \mathrm{E}$} & Nicotine self-administration blocked (infusion in VTA) & Corrigall et al. [86•] \\
\hline & & Nicotine CPP blocked & Walters et al. [84] \\
\hline & & Evoked DA release blocked & Zhou et al. [88] \\
\hline & & Anxiolytic (EPM; marble burying) & Anderson and Brunzell [131] \\
\hline & & Antidepressant-like (tail suspension; forced swim) & Andreasen et al. [139] \\
\hline & & Precipitates somatic signs of withdrawal & Epping-Jordan et al. [120]; Damaj et al. [116], Malin et al. [114] \\
\hline & & Precipitates withdrawal-induced increases in anxiety (EPM) & Jackson et al. [149] \\
\hline & & Precipitates withdrawal-induced increases in ICSS & Epping-Jordan et al. [120] \\
\hline & \multirow[t]{3}{*}{ Varenicline } & Anxiolytic (marble burying, $\mathrm{NIH}$ ) & Turner et al. [130]; Hussman et al. [132] \\
\hline & & Antidepressant-like (forced swim) & Rollema et al. [137]; Caldarone et al. [140] \\
\hline & & Reduces withdrawal-induced increases in ICSS thresholds & Igari et al. [123] \\
\hline & ABT-089 & $\begin{array}{l}\text { Anxiolytic during nicotine withdrawal and anxiogenic in } \\
\text { naïve mice (NIH) }\end{array}$ & Yohn et al. [133] \\
\hline & Cytisine & Antidepressant-like (tail suspension; forced swim) & Mineur et al. [138] \\
\hline & \multirow[t]{2}{*}{ A- 85380} & Trained rats self-administer this selective agonist & Liu et al. [90] \\
\hline & & Antidepressant-like (forced swim) & Buckley et al. [136]; Caldarone et al. [140] \\
\hline$\beta 3$ & KO & Decreased anxiety levels (EPM) & Booker et al. [144] \\
\hline \multirow[t]{3}{*}{$\beta 4$} & \multirow[t]{2}{*}{$\mathrm{KO}$} & Decreased anxiety levels (EPM; light dark) & Salas et al. [143]; Semenova et al. [145] \\
\hline & & Reduced withdrawal-induced somatic signs and hyperalgesia & $\begin{array}{l}\text { Salas et al. [117]; Stoker et al. [125]; Jackson } \\
\text { et al. [127] }\end{array}$ \\
\hline & $\alpha$-CTX AuIB & Precipitates nicotine withdrawal-induced somatic signs & Jackson et al. [127] \\
\hline$\alpha 2$ & $\mathrm{KO}$ & Increased self-administration & Lotfipour et al. [104] \\
\hline \multirow[t]{9}{*}{$\alpha 4$} & \multirow[t]{5}{*}{ KO } & $\begin{array}{l}\text { Nicotine self-administration blocked (rescued by re-expression } \\
\text { in VTA) and blunted nicotine-stimulated DA release }\end{array}$ & Pons et al. [83]; Exley et al. [91] \\
\hline & & CPP blocked and blunted nicotine-stimulated DA release & McGranahan et al. [92] \\
\hline & & Blunted basal and nicotine-stimulated DA release & Marubio et al. [93] \\
\hline & & Nicotine-stimulated anxiolysis blocked & McGranahan et al. [92] \\
\hline & & Increased anxiety levels (EPM) & Ross et al. [134] \\
\hline & L9S & Anxiogenic (EPM; mirrored chamber) & Labarca et al. [135] \\
\hline & L9A & $\begin{array}{l}\text { Hypersensitive to nicotine-stimulated DAergic neuron firing } \\
\text { and nicotine CPP }\end{array}$ & Tapper et al. [94] \\
\hline & \multirow[t]{2}{*}{ Sazetidine } & Anxiolytic (NIH) & Hussman et al. [132] \\
\hline & & Antidepressant (tail suspension; forced swim) & Turner et al. [130]; Caldarone et al. [140] \\
\hline \multirow[t]{3}{*}{$\alpha 5$} & \multirow[t]{3}{*}{ KO } & Increased nicotine self-administration & Fowler et al. [103] \\
\hline & & Reduced nicotine withdrawal-induced somatic signs & $\begin{array}{l}\text { Jackson et al. [119]; Salas et al. [128]; } \\
\text { Jackson et al. [127] }\end{array}$ \\
\hline & & Nicotine withdrawal-induced increases in anxiety intact (EPM) & Jackson et al. [119] \\
\hline
\end{tabular}


Table 2 (continued)

\begin{tabular}{|c|c|c|c|}
\hline Subunit & Manipulation & Behavioral Outcome & Reference \\
\hline \multirow[t]{7}{*}{$\alpha 6$} & \multirow[t]{2}{*}{$\mathrm{KO}$} & Nicotine CPP blocked & Sanjakdar et al. [98] \\
\hline & & $\begin{array}{l}\text { Nicotine self-administration blocked (rescued by re-expression } \\
\text { in VTA) and blunted nicotine-stimulated DA release }\end{array}$ & $\begin{array}{l}\text { Pons et al. [83]; Gotti et al. [97]; } \\
\text { Exley et al. [91] }\end{array}$ \\
\hline & \multirow[t]{2}{*}{ L9S } & Hypersensitive DAergic neuron firing and DA release & Drenan et al. [101] \\
\hline & & $\alpha 4$ co-expression required for hyperlocomotion & Drenan et al. [102] \\
\hline & \multirow{3}{*}{$\begin{array}{l}\alpha \text {-CTX MII } \\
\alpha \text {-CTX PIA }\end{array}$} & Nicotine CPP blocked & Jackson et al. [95]; Sanjakdar et al. [98] \\
\hline & & Nicotine self-administration blocked (infusion NAc and VTA) & Brunzell et al. [96]; Gotti et al. [97] \\
\hline & & Blocks nicotine-stimulated DAergic neuron firing & Liu et al. [99] \\
\hline \multirow[t]{20}{*}{$\alpha 7$} & \multirow[t]{9}{*}{$\mathrm{KO}$} & Leftward shift in nicotine CPP (enhanced at low doses) & Harenza et al. [107] \\
\hline & & Nicotine self-administration unaffected & Pons et al. [83] \\
\hline & & $\begin{array}{l}\text { Nicotine-stimulated DA release increased, nicotine self- } \\
\text { administration blunted }\end{array}$ & Besson et al. [111] \\
\hline & & Chronic oral nicotine intake decreased & Levin et al. [112] \\
\hline & & Anxiety-like behavior unaffected (EPM; light dark; open field) & Salas et al. [124]; Jackson et al. [119] \\
\hline & & Loss of nicotine withdrawal-induced increases in somatic signs & Jackson et al. [119]; Stoker et al. [125] \\
\hline & & $\begin{array}{l}\text { Spontaneous nicotine withdrawal-induced increases in anxiety } \\
\text { intact }\end{array}$ & Jackson et al. [119] \\
\hline & & MEC precipitated nicotine withdrawal-induced anxiety reduced & Jackson et al. [119] \\
\hline & & $\begin{array}{l}\text { Leftward shift in MEC dose response curve, as measured by } \\
\text { withdrawal- } \\
\text { induced increases in ICSS thresholds }\end{array}$ & Stoker et al. [125] \\
\hline & \multirow[t]{7}{*}{ MLA } & Nicotine self-administration unaffected & Grottick et al. [108] \\
\hline & & Nicotine self-administration blocked & Markou and Paterson [109] \\
\hline & & Reversed nicotine-induced anxiogenesis & Tucci et al. [146] \\
\hline & & Antidepressant (tail suspension; forced swim) & Andreasen et al. [139] \\
\hline & & $\begin{array}{l}\text { Precipitates nicotine withdrawal-induced increases in somatic } \\
\text { signs }\end{array}$ & $\begin{array}{l}\text { Markou and Paterson [109]; Damaj et al. } \\
\text { [116]; Salas et al. [124] }\end{array}$ \\
\hline & & $\begin{array}{l}\text { No effect on nicotine withdrawal-induced increases in anxiety } \\
\text { (EPM) }\end{array}$ & Damaj et al. [116] \\
\hline & & $\begin{array}{l}\text { No effect on nicotine withdrawal-induced increases in ICSS } \\
\text { thresholds }\end{array}$ & Markou and Paterson [109] \\
\hline & $\alpha-\mathrm{CTX}$ ArIB & Nicotine self-administration increased (NAc and ACC infusion) & Brunzell et al. [106] \\
\hline & PHA-543613 & Nicotine CPP blocked & Harenza et al. [107] \\
\hline & \multirow[t]{2}{*}{ PNU-282987 } & Nicotine self-administration blocked (NAc infusion) & Brunzell et al. [106] \\
\hline & & Increased anxiety levels & Pandya et al. [147] \\
\hline
\end{tabular}

Abbreviations: nicotinic acetylcholine receptor non-selective antagonist mecamylamine (MEC), semi-selective antagonist methyllycaconitine (MLA), selective antagonists dihydro-beta-erythroidine (DH $\beta$ E), $\alpha$ conotoxin MII ( $\alpha$-CTX MII), PIA ( $\alpha$-CTX PIA), ArIB ( $\alpha$-CTX ArIB) and AuIB ( $\alpha$-CTX AuIB), selective partial agonists (cytisine, varenicline, sazetidine, ABT-089), selective agonists (A-85830; PHA-54613; PNU282987); leucine to serine (L9S) or leucine to alanine (L9A) single point mutation in pore forming domain resulting in gain-of-function phenotype; null mutation of subunit resulting in total "knock out" of the receptor (KO); brain areas tested include ventral tegmental area (VTA), nucleus accumbens (NAc) and anterior cingulate cortex (ACC); and behavioral assays tested include conditioned place preference (CPP), elevated plus maze (EPM), novelty induced hypophagia (NIH) and intracranial self stimulation (ICSS)

$\beta 2 * n A C h R$ agonist varenicline relieved increases in ICSS thresholds instigated by spontaneous nicotine withdrawal [123], presumably due to stimulation of $\beta 2 * n A C h R s$ since $\mathrm{DH} \beta \mathrm{E}$ administration promotes withdrawal-induced increases in ICSS thresholds [120]. Contrary to pharmacological data, however, studies utilizing $\beta 2 \mathrm{KO}$ mice show that withdrawal-associated anxiety is absent in the $\beta 2 \mathrm{KO}$ mice but that somatic signs remain intact $[117,119]$, suggesting a strong role for $\beta 2 * n A C h R s$ in mediating the affective signs of nicotine withdrawal but indicating that $\beta 2 * n A C h R$ mediation of physical withdrawal symptoms requires further validation.

Studies assessing $\alpha 7 \mathrm{nAChR}$ contributions to withdrawal have utilized MLA and $\alpha 7 \mathrm{KO}$ mice. MLA-precipitated nicotine withdrawal induces somatic withdrawal signs $[109,116$, 124]. This is presumably due to MLA properties at $\alpha 7$ nAChRs since CTX antagonism of $\alpha 6^{*}$ nAChRs blocked 
withdrawal-induced conditioned place aversion (CPA) and had no effect on somatic withdrawal measures [95]. In contrast, deletion of the $\alpha 7$ subunit blocked observation of somatic withdrawal $[119,125]$. Together these data indicate a decisive role for $\alpha 7 \mathrm{nAChRs}$ in the expression of physical withdrawal. $\alpha 7 \mathrm{nAChR}$-mediated affective signs, however, are somewhat inconclusive. Whereas MLA-precipitated withdrawal does not elevate anxiety in the EPM [116] or elevate ICSS thresholds following chronic nicotine exposure [109], studies using $\alpha 7 \mathrm{KO}$ mice indicate a potential role of $\alpha 7$ nAChRs in affective withdrawal. Spontaneous withdrawal does not change anxiety in the $\alpha 7 \mathrm{KO}$ compared to wild-type mice [119], however precipitated withdrawal with $2 \mathrm{mg} / \mathrm{kg}$ MEC results in reduced anxiety-like behavior in the EPM task [119]. Indeed, $\alpha 7 \mathrm{KO}$ mice show elevated ICSS thresholds in response to precipitation of nicotine withdrawal at lower doses of MEC (1.5 mg/kg) than WT mice (3 and $6 \mathrm{mg} / \mathrm{kg}$ ) [125], suggesting a leftward shift in the dose response curve for MEC effects rather than a withdrawal deficit in these mice. Since mRNA levels of other nAChR subunits are unchanged in the $\alpha 7 \mathrm{KO}$ mouse [126], differences in responses to MEC are unlikely due to compensatory changes in other nAChRs but this does not preclude alterations in other neurotransmitter systems.

The habenula, a brain area enriched with $\alpha 3 \beta 4 *_{n} A C h R s$ and $\alpha 5^{*} \mathrm{nAChRs}$, is receiving increasing attention for its contributions to nicotine dependence. Genetic deletion of the $\beta 4$ $\mathrm{nAChR}$ subunit is associated with reduced somatic withdrawal signs [117, 125, 127] and hyperalgesia [117]. Somatic signs of nicotine withdrawal can also be precipitated by intracerebroventricular (i.c.v) administration of AuIB, a selective $\alpha 3 \beta 4$ antagonist [127]. This effect is not altered by deletion of the $\alpha 5$ subunit, suggesting that $\alpha 3 \alpha 5 \beta 4 *$ nAChRs are not critical for expression of physical withdrawal. Other (non- $\alpha 3 \beta 4) \alpha 5^{*}$ nAChRs may contribute to withdrawal, as deletion of the $\alpha 5$ subunit results in decreased somatic signs when withdrawal is precipitated with the non-specific nAChR antagonist, MEC $[119,127,128]$. $\alpha 5 \mathrm{KO}$ studies suggest that $\alpha 5^{*}$ nAChRs do not contribute to withdrawal-associated increases in anxiety behavior [119]. These data suggest a role for independent $\alpha 5^{*}$ and $\beta 4^{*} \mathrm{nAChRs}$ in mediating physical signs of withdrawal, but further validation is required to confirm a role for these subunits in affective behavioral withdrawal signs.

\section{Anxiety- and Depression-Like Behavior}

Many smokers report that they smoke to relieve anxiety and there is a high concordance of anxiety and major depression diagnoses with smoking [129]. Although these are complex emotions that cannot be entirely assessed in animals, rodent models of anxiety and antidepressant efficacy suggest that nAChRs contribute to the biology of affective behaviors associated with nicotine use.
Unlike reward and reinforcement, where a preponderance of the evidence suggests that activation of $\beta 2 * n A C h R s$ is essential for these behaviors, an accumulation of rodent data indicate that inhibition of $\beta 2 * n A C h R s$ promotes anxiolysislike behavior. The $\beta 2 *_{n} A C h R$ antagonist, $\mathrm{DH} \beta \mathrm{E}$, and partial agonists varenicline, ABT-089, and sazetidine promote anxiolysis-like behavior in the EPM, marble burying, and conditioned inhibition tasks [130-133]. Low-dose nicotine mimics anxiolysis-like effects of $\mathrm{DH} \beta \mathrm{E}$, suggesting that desensitization of nAChRs by low doses of nicotine may decrease anxiety [131]. A study using mice lacking nAChR $\alpha 4$ subunits in the VTA showed that these mice failed to benefit from the anxiolytic-like effects of low-dose nicotine, suggesting that $\alpha 4 \beta 2 *$ nAChRs in the VTA are required for nicotineinduced anxiolysis in the EPM [92] (but see [134]). In contrast, L9A mice with gain-of-function $\alpha 4 \beta 2 *$ nAChRs show increased basal anxiety in the EPM [135] to suggest that stimulation of the $\alpha 4{ }^{*} \mathrm{nAChRs}$ is sufficient to promote anxiety, presumably in brain areas other than those that support nicotine reward and reinforcement.

Similarly, DH $\beta E$ and the $\alpha 4 \beta 2 *^{*}$ AChRs partial agonists varenicline, sazetidine, and cytisine have been shown to produce antidepressant-like effects in the forced swim and tail suspension tests in mice [130, 136-140]. Studies in knockout mice reveal that $\beta 2 *_{n} \mathrm{AChRs}$ regulate the antidepressant-like efficacy of MEC and its potentiation of the classic antidepressant, amitriptyline [141, 142]. Curiously, recent data suggest that stimulation of $\alpha 4 \beta 2 * \mathrm{nAChRs}$ promotes antidepressant effects of sazetidine [140]. Further data are necessary to determine whether stimulation or inhibition of $\alpha 4 \beta 2 *$ nAChRs may benefit smokers with depression.

Studies implicate other nAChR subunits in affective behavior. Mice with a null mutation of the $\beta 4$ or $\beta 3$ subunit show less basal anxiety-like behavior than wild-type mice in the EPM, light dark, and prepulse inhibition tasks [143-145], suggesting that cholinergic tone at these receptors may support anxiety phenotype. $\alpha 7 \mathrm{KO}$ mice show similar basal anxiety levels as WT mice in open field, EPM, and light dark tests [119, 124]. Other studies show that intrahippocampal MLA reverses nicotine-induced anxiogenesis in the social interaction test [146] and that systemic administration of the selective $\alpha 7$ nAChR agonist, PNU-282987, increases anxiety-like behavior [147], suggesting that inhibition of $\alpha 7 \mathrm{nAChRs}$ may decrease anxiety behavior. Together, these studies suggest that the endogenous cholinergic system regulates emotive behaviors that could be targeted by nicotine in individuals who use tobacco products.

\section{Summary and Therapeutic Implications}

Although FDA-approved first-line smoking cessation drugs greatly improve quit outcomes, a limited number of smokers 
are successful at quitting with currently available therapeutics [148]. A diversity of neuronal nAChRs may provide novel targets for assisting unique populations of smokers to quit. Human genetics studies have implicated a variety of $\mathrm{nAChR}$ subunits as contributing to risk for tobacco dependence phenotype. The strongest GWAS candidate thus far is CHRNA5. The $\alpha 5 \mathrm{nAChR}$ subunit affects agonist and antagonist binding affinity and potency, but as an accessory subunit does not contribute to agonist binding and therefore is not an ideal drug target. Large GWAS studies have relied primarily upon the FTND scores. Smaller gene-targeted studies have begun to assess alternate $\mathrm{nAChR}$ subunit contributions to a variety of behavioral phenotypes that support tobacco use. Where GWAS failed to identify strong associations of $\alpha 4, \alpha 6, \beta 2$, or $\alpha 7$ with tobacco dependence, targeted gene studies have implicated variations in these subunits as contributing to smoking phenotype. This is relevant as these nAChR subunits assemble to make nAChRs that are targeted by the smoking cessation therapeutic, varenicline. Although genetic studies identify risk variants for tobacco dependence, they do not rule out the relevance of targets that do not show significant genetic variability across the populace. Human and animal preclinical laboratory studies are necessary to identify these alternative viable $\mathrm{nAChR}$ targets for smoking cessation and to establish a functional strategy for inhibition or stimulation of specific nAChR subtypes to promote a desired phenotypic effect. As with animal models, controlled human laboratory studies should strive to parse behaviors that are relevant to tobacco addiction in order to develop tailored treatments for individuals according to their motives for smoking. With clinical assessment tools to reliably identify motives for smoking, we can perhaps expect the best outcomes for identifying strategies for quitting.

\section{Compliance with Ethics Guidelines}

Conflict of Interest Dr. Darlene Brunzell is the principal investigator of NIH grants R01 DA031289 "Nicotinic receptor contributions to affective behavior," UH2/UH3 TR000958 "Medication development of a novel therapeutic for smoking cessation," and Virginia Foundation for Healthy Youth Grant 8520893 "Exercise and environmental enrichment as a prevention strategy for nicotine use in adolescent males and females". Dr. Brunzell contributes as a co-investigator to NIH P30 DA033934 "Central Virginia Drug Abuse Core" to Dr. William L Dewey, R01 AG041161 "Novel bivalent multifunctional ligands towards Alzheimer's disease" to Dr. Shijun Zhang and NIAAA P50 AA022537 "Cross-species investigation of gene networks for ethanol-related behaviors" to Dr. Kenneth S. Kendler. Alexandra M. Stafford contributes to studies assessing nAChR contributions to behaviors relevant to smoking phenotype. She is supported by an NIDA training grant T32 DA 007027 to Dr. William L Dewey. Dr. Claire Dixon contributes to studies assessing nAChR contributions to behaviors relevant to smoking phenotype.

Human and Animal Rights and Informed Consent This article does not contain any studies with human or animal subjects performed by any of the authors.

\section{References}

Papers of particular interest, published recently, have been highlighted as:

- Of importance

1. Brunzell DH, McIntosh JM, Papke RL. Diverse strategies targeting $\alpha 7$ homomeric and $\alpha 6 \beta 2 *$ heteromeric nicotinic acetylcholine receptors for smoking cessation. Ann N Y Acad Sci. 2014. doi:10.1111/nyas.12421.

2. Clarke PB, Schwartz RD, Paul SM, et al. Nicotinic binding in rat brain: autoradiographic comparison of $[3 \mathrm{H}]$ acetylcholine, $[3 \mathrm{H}]$ nicotine, and [125I]-alpha-bungarotoxin. J Neurosci. 1985;5:1307-15.

3. Séguéla P, Wadiche J, Dineley-Miller K, et al. Molecular cloning, functional properties, and distribution of rat brain alpha 7: a nicotinic cation channel highly permeable to calcium. J Neurosci. 1993;13:596-604.

4. Zoli M, Léna C, Picciotto MR, Changeux JP. Identification of four classes of brain nicotinic receptors using beta2 mutant mice. J Neurosci. 1998;18:4461-72.

5. Grady SR, Moretti M, Zoli M, et al. Rodent habenulointerpeduncular pathway expresses a large variety of uncommon nAChR subtypes, but only the alpha3beta $4 *$ and alpha3beta3beta4* subtypes mediate acetylcholine release. J Neurosci. 2009;29:2272-82. doi:10.1523/JNEUROSCI. 5121-08.2009.

6. Scholze P, Koth G, Orr-Urtreger A, Huck S. Subunit composition of $\alpha 5$-containing nicotinic receptors in the rodent habenula. $\mathrm{J}$ Neurochem. 2012;121:551-60. doi:10.1111/j.1471-4159.2012. 07714.x.

7. Shih P-Y, Engle SE, Oh G, et al. Differential expression and function of nicotinic acetylcholine receptors in subdivisions of medial habenula. J Neurosci. 2014;34:9789-802. doi:10.1523/ JNEUROSCI. 0476-14.2014.

8. Heatherton TF, Kozlowski LT, Frecker RC, Fagerström KO. The Fagerström test for nicotine dependence: a revision of the Fagerström Tolerance Questionnaire. Br J Addict. 1991;86: 1119-27.

9. Ehringer MA, Clegg HV, Collins AC, et al. Association of the neuronal nicotinic receptor beta2 subunit gene (CHRNB2) with subjective responses to alcohol and nicotine. Am J Med Genet B Neuropsychiatr Genet. 2007;144B:596-604. doi:10.1002/ajmg.b. 30464.

10. Conti DV, Lee W, Li D, et al. Nicotinic acetylcholine receptor beta2 subunit gene implicated in a systems-based candidate gene study of smoking cessation. Hum Mol Gen. 2008;17:2834-48. doi:10.1093/hmg/ddn181.

11. Perkins KA, Lerman C, Mercincavage M, et al. Nicotinic acetylcholine receptor $\beta 2$ subunit (CHRNB2) gene and short-term ability to quit smoking in response to nicotine patch. Cancer Epidemiol Biomarkers Prev. 2009;18:2608-12. doi:10.1158/ 1055-9965.EPI-09-0166.

12. Wessel J, McDonald SM, Hinds DA, et al. Resequencing of nicotinic acetylcholine receptor genes and association of common and rare variants with the Fagerström Test for Nicotine Dependence. Neuropsychopharmacology. 2010;35:2392-402. doi:10.1038/npp.2010.120.

13. Hoft NR, Stitzel JA, Hutchison KE, Ehringer MA. CHRNB2 promoter region: association with subjective effects to nicotine and gene expression differences. Genes Brain Behav. 2011;10:17685. doi:10.1111/j.1601-183X.2010.00650.x. 
14. King DP, Paciga S, Pickering E, et al. Smoking cessation pharmacogenetics: analysis of varenicline and bupropion in placebocontrolled clinical trials. Neuropsychopharmacology. 2012;37: 641-50. doi:10.1038/npp.2011.232.

15. Saccone NL, Saccone SF, Hinrichs AL, et al. Multiple distinct risk loci for nicotine dependence identified by dense coverage of the complete family of nicotinic receptor subunit (CHRN) genes. Am J Med Genet. 2009;150B:453-66. doi:10.1002/ajmg.b.30828.

16. Berrettini W, Yuan X, Tozzi F, et al. $\alpha 5 / \alpha 3$ nicotinic receptor subunit alleles increase risk for heavy smoking. Mol Psychiatry. 2008;13:368-73. doi:10.1038/sj.mp.4002154. It has proved very difficult with GWAS studies to identify reliable candidate genes for complex psychiatric disorders. These are among the first studies to provide convincing evidence that SNPS in the CHRNA3/CHRN A5/CHRNB4 gene cluster are associated with vulnerability to tobacco dependence phenotype.

17. Thorgeirsson TE, Geller F, Sulem P, et al. A variant associated with nicotine dependence, lung cancer and peripheral arterial disease. Nature. 2008;452:638-42. doi:10.1038/nature06846. It has proved very difficult with GWAS studies to identify reliable candidate genes for complex psychiatric disorders. These are among the first studies to provide convincing evidence that SNPS in the CHRNA3/CHRNA5/CHRNB4 gene cluster are associated with vulnerability to tobacco dependence phenotype.

18. Bierut LJ, Stitzel JA, Wang JC, et al. Variants in nicotinic receptors and risk for nicotine dependence. Am J Psychiatry. 2008;165: 1163-71. doi:10.1176/appi.ajp.2008.07111711. It has proved very difficult with GWAS studies to identify reliable candidate genes for complex psychiatric disorders. These are among the first studies to provide convincing evidence that SNPS in the CHRNA3/CHRNA5/CHRNB4 gene cluster are associated with vulnerability to tobacco dependence phenotype.

19. Feng Y, Niu T, Xing H, et al. A common haplotype of the nicotine acetylcholine receptor alpha 4 subunit gene is associated with vulnerability to nicotine addiction in men. Am J Hum Genet. 2004;75:112-21. doi:10.1086/422194.

20. Li MD. Ethnic- and gender-specific association of the nicotinic acetylcholine receptor $\alpha 4$ subunit gene (CHRNA4) with nicotine dependence. Hum Mol Gen. 2005;14:1211-9. doi:10.1093/ hmg/ddi132.

21. Lueders $\mathrm{KK}, \mathrm{Hu} \mathrm{S}, \mathrm{McHugh} \mathrm{L}$, et al. Genetic and functional analysis of single nucleotide polymorphisms in the beta2neuronal nicotinic acetylcholine receptor gene (CHRNB2). Nicotine Tob Res. 2002;4:115-25. doi:10.1080/ 14622200110098419.

22. Silverman MA, Neale MC, Sullivan PF, et al. Haplotypes of four novel single nucleotide polymorphisms in the nicotinic acetylcholine receptor beta2-subunit (CHRNB2) gene show no association with smoking initiation or nicotine dependence. Am J Med Genet. 2000;96:646-53.

23. Schlaepfer IR, Hoft NR, Collins AC, et al. The CHRNA5/A3/B4 gene cluster variability as an important determinant of early alcohol and tobacco initiation in young adults. Biol Psychiatry. 2008;63:1039-46. doi:10.1016/j.biopsych.2007.10.024.

24. Hong LE, Hodgkinson CA, Yang Y, et al. A genetically modulated, intrinsic cingulate circuit supports human nicotine addiction. Proc Natl Acad Sci U S A. 2010;107:13509-14. doi:10.1073/ pnas. 1004745107.

25. Keskitalo K, Broms U, Heliovaara M, et al. Association of serum cotinine level with a cluster of three nicotinic acetylcholine receptor genes (CHRNA3/CHRNA5/CHRNB4) on chromosome 15. Hum Mol Gen. 2009;18:4007-12. doi:10.1093/hmg/ddp322.

26. Chen X, Chen J, Williamson VS, et al. Variants in nicotinic acetylcholine receptors $\alpha 5$ and $\alpha 3$ increase risks to nicotine dependence. Am J Med Genet. 2009;150B:926-33. doi:10.1002/ajmg. b.30919.
27. Munafo MR, Timofeeva MN, Morris RW, et al. Association between genetic variants on chromosome $15 \mathrm{q} 25$ locus and objective measures of tobacco exposure. J Natl Cancer Inst. 2012;104:740 8. doi:10.1093/jnci/djs191.

28. Stevens VL, Bierut LJ, Talbot JT, et al. Nicotinic receptor gene variants influence susceptibility to heavy smoking. Cancer Epidemiol Biomarkers Prev. 2008;17:3517-25. doi:10.1158/ 1055-9965.EPI-08-0585.

29. Saccone SF, Hinrichs AL, Saccone NL, et al. Cholinergic nicotinic receptor genes implicated in a nicotine dependence association study targeting 348 candidate genes with 3713 SNPs. Hum Mol Gen. 2007;16:36-49. doi:10.1093/hmg/ddl438.

30. Voineskos S, De Luca V, Mensah A, et al. Association of alpha4beta2 nicotinic receptor and heavy smoking in schizophrenia. J Psychiatry Neurosci. 2007;32:412-6.

31. Saccone NL, Schwantes-An T-H, Wang JC, et al. Multiple cholinergic nicotinic receptor genes affect nicotine dependence risk in African and European Americans. Genes Brain Behav. 2010;9: 741-50. doi:10.1111/j.1601-183X.2010.00608.x.

32. Han S, Yang B-Z, Kranzler HR, et al. Association of CHRNA4 polymorphisms with smoking behavior in two populations. Am J Med Genet. 2011;156:421-9. doi:10.1002/ajmg.b.31177.

33. Kamens HM, Corley RP, McQueen MB, et al. Nominal association with CHRNA4 variants and nicotine dependence. Genes Brain Behav. 2013;12:297-304. doi:10.1111/gbb.12021.

34. Hutchison KE, Allen DL, Filbey FM, et al. CHRNA4 and tobacco dependence: from gene regulation to treatment outcome. Arch Gen Psychiatry. 2007;64:1078-86. doi:10.1001/archpsyc.64.9. 1078.

35. Xie P, Kranzler HR, Krauthammer M, et al. Rare nonsynonymous variants in alpha-4 nicotinic acetylcholine receptor gene protect against nicotine dependence. Biol Psychiatry. 2011;70:528-36. doi:10.1016/j.biopsych.2011.04.017.

36. McClure-Begley TD, Papke RL, Stone KL, et al. Rare human nicotinic acetylcholine receptor $\alpha 4$ subunit (CHRNA4) variants affect expression and function of high-affinity nicotinic acetylcholine receptors. J Pharmacol Exp Ther. 2014;348:410-20. doi:10. 1124/jpet.113.209767.

37. Hoft NR, Corley RP, McQueen MB, et al. Genetic association of the CHRNA6 and CHRNB3 genes with tobacco dependence in a nationally representative sample. Neuropsychopharmacology. 2009;34:698-706. doi:10.1038/npp.2008.122.

38. Thorgeirsson TE, Gudbjartsson DF, Surakka I, et al. Sequence variants at CHRNB3-CHRNA6 and CYP2A6 affect smoking behavior. Nat Genet. 2010;42:448-53. doi:10.1038/ng.573.

39. Wang S, van der Vaart AD, Xu Q, et al. Significant associations of CHRNA2 and CHRNA6 with nicotine dependence in European American and African American populations. Hum Genet. 2013;133:575-86. doi:10.1007/s00439-013-1398-9.

40. Culverhouse RC, Johnson EO, Breslau N, et al. Multiple distinct CHRNB3-CHRNA6 variants are genetic risk factors for nicotine dependence in African Americans and European Americans. Addiction. 2014;109:814-22. doi:10.1111/add.12478.

41. Zeiger JS, Haberstick BC, Schlaepfer I, et al. The neuronal nicotinic receptor subunit genes (CHRNA6 and CHRNB3) are associated with subjective responses to tobacco. Hum Mol Gen. 2007;17:724-34. doi:10.1093/hmg/ddm344.

42. Ebbert JO. Varenicline and combination nicotine replacement therapy are the most effective pharmacotherapies for treating tobacco use. Evid Based Med. 2013;18:212-3. doi:10.1136/eb2013-101462.

43. Cahill K, Stevens S, Lancaster T. Pharmacological treatments for smoking cessation. JAMA. 2014;311:193-4. doi:10.1001/jama. 2013.283787.

44. Jorenby DE, Hays JT, Rigotti NA, et al. Efficacy of varenicline, an alpha4beta2 nicotinic acetylcholine receptor partial agonist, vs 
placebo or sustained-release bupropion for smoking cessation: a randomized controlled trial. JAMA. 2006;296:56-63. doi:10. 1001/jama.296.1.56.

45. Gonzales D, Rennard SI, Nides M, et al. Varenicline, an alpha4beta2 nicotinic acetylcholine receptor partial agonist, vs sustained-release bupropion and placebo for smoking cessation: a randomized controlled trial. JAMA. 2006;296:47-55. doi:10. 1001/jama.296.1.47.

46. Fagerström K, Hughes J. Varenicline in the treatment of tobacco dependence. Neuropsychiatr Dis Treat. 2008;4:353-63.

47. Brody AL, Mandelkern MA, London ED, et al. Cigarette smoking saturates brain alpha4beta2 nicotinic acetylcholine receptors. Arch Gen Psychiatry. 2006;63:907-15. doi:10.1001/archpsyc.63.8.907. This imaging study shows that smoking a single cigarette is sufficient to occupy $80 \%$ of $\beta 2 * n A C h R s$ in brain, indicating that this subtype is significantly engaged during smoking. Additionally, this study showed [nicotine] occupancy of these high affinity receptors lasts for over 3 hours.

48. Buisson B, Bertrand D. Chronic exposure to nicotine upregulates the human (alpha)4(beta)2 nicotinic acetylcholine receptor function. J Neurosci. 2001;21:1819-29.

49. Benwell ME, Balfour DJ, Anderson JM. Evidence that tobacco smoking increases the density of $(-)-[3 \mathrm{H}]$ nicotine binding sites in human brain. J Neurochem. 1988;50:1243-7.

50. Breese CR, Marks MJ, Logel J, et al. Effect of smoking history on $[3 \mathrm{H}]$ nicotine binding in human postmortem brain. J Pharmacol Exp Ther. 1997;282:7-13.

51. Staley JK, Krishnan-Sarin S, Cosgrove KP, et al. Human tobacco smokers in early abstinence have higher levels of beta $2 *$ nicotinic acetylcholine receptors than nonsmokers. J Neurosci. 2006;26: 8707-14. doi:10.1523/JNEUROSCI. 0546-06.2006.

52. Mamede M, Ishizu K, Ueda M, et al. Temporal change in human nicotinic acetylcholine receptor after smoking cessation: 5IA SPECT study. J Nucl Med. 2007;48:1829-35. doi:10.2967/ jnumed.107.043471.

53. Cosgrove KP, Batis J, Bois F, et al. beta2-Nicotinic acetylcholine receptor availability during acute and prolonged abstinence from tobacco smoking. Arch Gen Psychiatry. 2009;66:666-76. doi:10. 1001/archgenpsychiatry.2009.41.

54. Brody AL, Mukhin AG, Mamoun MS, et al. Brain nicotinic acetylcholine receptor availability and response to smoking cessation treatment: a randomized trial. JAMA. 2014;71:797-805. doi:10. 1001/jamapsychiatry.2014.138.

55. Sherva R, Wilhelmsen K, Pomerleau CS, et al. Association of a single nucleotide polymorphism in neuronal acetylcholine receptor subunit alpha 5 (CHRNA5) with smoking status and with "pleasurable buzz" during early experimentation with smoking. Addiction. 2008;103:1544-52. doi:10.1111/j.1360-0443.2008. 02279.x.

56. Grucza RA, Johnson EO, Krueger RF, et al. Incorporating age at onset of smoking into genetic models for nicotine dependence: evidence for interaction with multiple genes. Addict Biol. 2010;15:346-57. doi:10.1111/j.1369-1600.2010.00220.x.

57. Liu JZ, Tozzi F, Waterworth DM, et al. Meta-analysis and imputation refines the association of $15 \mathrm{q} 25$ with smoking quantity. Nat Genet. 2010;42:436-40. doi:10.1038/ng.572.

58. George AA, Lucero LM, Damaj MI, et al. Function of human $\alpha 3 \beta 4 \alpha 5$ nicotinic acetylcholine receptors is reduced by the 5(D398N) variant. J Biol Chem. 2012;287:25151-62. doi:10. 1074/jbc.M112.379339.

59. Tammimäki A, Herder P, Li P, et al. Impact of human D398N single nucleotide polymorphism on intracellular calcium response mediated by $\alpha 3 \beta 4 \alpha 5$ nicotinic acetylcholine receptors. Neuropharmacology. 2012;63:1002-11. doi:10.1016/j. neuropharm.2012.07.022.
60. Morel C, Fattore L, Pons S, et al. Nicotine consumption is regulated by a human polymorphism in dopamine neurons. Mol Psychiatry. 2014;19:930-6. doi:10.1038/mp.2013.158.

61. Nees F, Witt SH, Lourdusamy A, et al. Genetic risk for nicotine dependence in the cholinergic system and activation of the brain reward system in healthy adolescents. Neuropsychopharmacology. 2013;38:2081-9. doi:10.1038/npp. 2013.131.

62. Greenbaum L, Kanyas K, Karni O, et al. Why do young women smoke? I. Direct and interactive effects of environment, psychological characteristics and nicotinic cholinergic receptor genes. Mol Psychiatry. 2005;11:312-22. doi:10.1038/sj.mp.4001774.

63. Philibert RA, Todorov A, Andersen A, et al. Examination of the Nicotine Dependence (NICSNP) Consortium findings in the Iowa adoption studies population. Nicotine Tob Res. 2009;11:286-92. doi:10.1093/ntr/ntn034.

64. Zammit S, Spurlock G, Williams H, et al. Genotype effects of CHRNA7, CNR1 and COMT in schizophrenia: interactions with tobacco and cannabis use. Brit J Psychiatry. 2007;191:402-7. doi: 10.1192/bjp.bp.107.036129.

65. Pedneault M, Labbe A, Roy-Gagnon M-H, et al. The association between CHRN genetic variants and dizziness at first inhalation of cigarette smoke. Addict Behav. 2014;39:316-20. doi:10.1016/j. addbeh.2013.08.033.

66. DiFranza JR, Savageau JA, Fletcher K, et al. Recollections and repercussions of the first inhaled cigarette. Addict Behav. 2004;29: 261-72. doi:10.1016/j.addbeh.2003.08.002.

67. Mihalak KB, Carroll FI, Luetje CW. Varenicline is a partial agonist at alpha4beta2 and a full agonist at alpha7 neuronal nicotinic receptors. Mol Pharmacol. 2006;70:801-05. doi:10.1124/mol.106. 025130. This neurochemistry report showed a surprising mechanism for Varenicline as a full agonist at alpha7 nAChRs, although at a lower potency than for its role as a partial agonist of $\beta 2 * n A C h R s$.

68. Hughes JR, Hatsukami DK, Mitchell JE, Dahlgren LA. Prevalence of smoking among psychiatric outpatients. Am J Psychiatry. 1986;143:993-7.

69. Menza MA, Grossman N, van Horn M, et al. Smoking and movement disorders in psychiatric patients. Biol Psychiatry. 1991;30: $109-15$.

70. Olincy A, Young DA, Freedman R. Increased levels of the nicotine metabolite cotinine in schizophrenic smokers compared to other smokers. Biol Psychiatry. 1997;42:1-5. doi:10.1016/ S0006-3223(96)00302-2.

71. Faraone SV, Su J, Taylor L, et al. A novel permutation testing method implicates sixteen nicotinic acetylcholine receptor genes as risk factors for smoking in schizophrenia families. hum hered. 2004;57:59-68. doi:10.1159/000077543.

72. De Luca V, Wong AH, Muller DJ, et al. Evidence of association between smoking and $\alpha 7$ nicotinic receptor subunit gene in schizophrenia patients. Neuropsychopharmacology. 2004;29: 1522-6. doi:10.1038/sj.npp.1300466.

73. Mexal S, Berger R, Logel J, et al. Differential regulation of alpha7 nicotinic receptor gene (CHRNA7) expression in schizophrenic smokers. J Mol Neurosci. 2010;40:185-95. doi:10.1007/s12031009-9233-4.

74. Freedman R, Hall M, Adler LE, Leonard S. Evidence in postmortem brain tissue for decreased numbers of hippocampal nicotinic receptors in schizophrenia. Biol Psychiatry. 1995;38:22-33. doi: 10.1016/0006-3223(94)00252-X.

75. Guan ZZ, Zhang X, Blennow K, Nordberg A. Decreased protein level of nicotinic receptor alpha7 subunit in the frontal cortex from schizophrenic brain. Neuroreport. 1999;10:1779-82.

76. Gault J, Robinson M, Berger R, et al. Genomic organization and partial duplication of the human alpha7 neuronal nicotinic 
acetylcholine receptor gene (CHRNA7). Genomics. 1998;52: 173-85. doi:10.1006/geno.1998.5363.

77. Adler LE, Hoffer LJ, Griffith J, et al. Normalization by nicotine of deficient auditory sensory gating in the relatives of schizophrenics. Biol Psychiatry. 1992;32:607-16.

78. Adler LE, Hoffer LD, Wiser A, Freedman R. Normalization of auditory physiology by cigarette smoking in schizophrenic patients. Am J Psychiatry. 1993;150:1856-61.

79. Freedman R, Coon H, Myles-Worsley M, et al. Linkage of a neurophysiological deficit in schizophrenia to a chromosome 15 locus. Proc Natl Acad Sci U S A. 1997;94:587-92.

80. Picciotto MR, Zoli M, Rimondini R, et al. Acetylcholine receptors containing the beta2 subunit are involved in the reinforcing properties of nicotine. Nature. 1998;391:173-7. doi:10.1038/34413. Mutant mouse studies have greatly enhanced our knowledge of $n A C h R$ anatomy, function and relevance to nicotine use and addiction phenotype. This early knockout study confirmed pharmacology studies performed by Corrigall and Coen to implicate $\beta 2^{*} n A C h R$ s in nicotine reinforcement and nicotineassociated dopamine release.

81. Maskos U, Molles BE, Pons S, et al. Nicotine reinforcement and cognition restored by targeted expression of nicotinic receptors. Nature. 2005;436:103-7. doi:10.1038/nature03694.

82. Besson M, David V, Suarez S, et al. Genetic dissociation of two behaviors associated with nicotine addiction: beta- 2 containing nicotinic receptors are involved in nicotine reinforcement but not in withdrawal syndrome. Psychopharmacology. 2006;187:18999. doi:10.1007/s00213-006-0418-z.

83. Pons S, Fattore L, Cossu G, et al. Crucial role of $\alpha 4$ and $\alpha 6$ nicotinic acetylcholine receptor subunits from ventral tegmental area in systemic nicotine self-administration. J Neurosci. 2008;28: 12318-27. doi:10.1523/JNEUROSCI. 3918-08.2008.

84. Walters CL, Brown S, Changeux J-P, et al. The beta2 but not alpha7 subunit of the nicotinic acetylcholine receptor is required for nicotine-conditioned place preference in mice. Psychopharmacology. 2006;184:339-44. doi:10.1007/s00213005-0295-x.

85. Brunzell DH, Chang JR, Schneider B, et al. beta2-Subunitcontaining nicotinic acetylcholine receptors are involved in nicotine-induced increases in conditioned reinforcement but not progressive ratio responding for food in C57BL/6 mice. Psychopharmacology. 2006;184:328-38. doi:10.1007/s00213005-0099-z.

86. Corrigall WA, Coen KM, Adamson KL. Self-administered nicotine activates the mesolimbic dopamine system through the ventral tegmental area. Brain Res. 1994;653:278-84. Mutant mouse studies have greatly enhanced our knowledge of nAChR anatomy, function and relevance to nicotine use and addiction phenotype. This early knockout study confirmed pharmacology studies performed by Corrigall and Coen to implicate $\beta 2 * n A C h R$ s in nicotine reinforcement and nicotine-associated dopamine release.

87. King SL, Caldarone BJ, Picciotto MR. Beta2-subunit-containing nicotinic acetylcholine receptors are critical for dopaminedependent locomotor activation following repeated nicotine administration. Neuropharmacology. 2004;47 Suppl 1:132-9. doi: 10.1016/j.neuropharm.2004.06.024.

88. Zhou FM, Liang Y, Dani JA. Endogenous nicotinic cholinergic activity regulates dopamine release in the striatum. Nat Neurosci. 2001;4:1224-9. doi:10.1038/nn769.

89. Mineur YS, Brunzell DH, Grady SR, et al. Localized low-level reexpression of high-affinity mesolimbic nicotinic acetylcholine receptors restores nicotine-induced locomotion but not place conditioning. Genes Brain Behav. 2009;8:257-66. doi:10.1111/j.1601183X.2008.00468.x.

90. Liu A, Koren AO, Yee SK, Pechnick RN,Poland RE, London ED Self-administration of 5-iodo-A-85380, a beta 2 -selective nicotinic receptor ligand, by operantly trained rats. Neuroreport. 2003;14:1503-1505.

91. Exley R, Maubourguet N, David V, et al. Distinct contributions of nicotinic acetylcholine receptor subunit alpha4 and subunit alpha6 to the reinforcing effects of nicotine. Proc Natl Acad Sci U S A. 2011;108:7577-82. doi:10.1073/pnas.1103000108.

92. McGranahan TM, Patzlaff NE, Grady SR, et al. $\alpha 4 \beta 2$ nicotinic acetylcholine receptors on dopaminergic neurons mediate nicotine reward and anxiety relief. J Neurosci. 2011;31:10891-902. doi:10. 1523/JNEUROSCI. 0937-11.2011.

93. Marubio LM, Gardier AM, Durier S, et al. Effects of nicotine in the dopaminergic system of mice lacking the alpha4 subunit of neuronal nicotinic acetylcholine receptors. Eur J Neurosci. 2003;17:1329-37.

94. Tapper AR, McKinney SL, Nashmi R, et al. Nicotine activation of alpha4* receptors: sufficient for reward, tolerance, and sensitization. Science. 2004;306:1029-32. doi:10.1126/science.1099420.

95. Jackson KJ, McIntosh JM, Brunzell DH, et al. The role of $\alpha 6$ containing nicotinic acetylcholine receptors in nicotine reward and withdrawal. J Pharmacol Exp Ther. 2009;331:547-54. doi:10. 1124/jpet.109.155457.

96. Brunzell DH, Boschen KE, Hendrick ES, et al. $\alpha$-Conotoxin MIIsensitive nicotinic acetylcholine receptors in the nucleus accumbens shell regulate progressive ratio responding maintained by nicotine. Neuropsychopharmacology. 2010;35:665-73. doi:10. 1038/npp.2009.171.

97. Gotti C, Guiducci S, Tedesco V, et al. Nicotinic acetylcholine receptors in the mesolimbic pathway: primary role of ventral tegmental area $\alpha 6 \beta 2 *$ receptors in mediating systemic nicotine effects on dopamine release, locomotion, and reinforcement. J Neurosci. 2010;30:5311-25. doi:10.1523/JNEUROSCI. 5095-09.2010.

98. Sanjakdar SS, Maldoon PP, Marks MJ, et al. Differential roles of $\alpha 6 \beta 2 *$ and $\alpha 4 \beta 2 *$ neuronal nicotinic receptors in nicotine and cocaine conditioned reward in mice. Neuropsychopharmacology. 2014. doi:10.1038/npp.2014.177.

99. Liu L, Zhao-Shea R, McIntosh JM, et al. Nicotine persistently activates ventral tegmental area dopaminergic neurons via nicotinic acetylcholine receptors containing $\alpha 4$ and $\alpha 6$ subunits. Mol Pharmacol. 2012;81:541-8. doi:10.1124/mol.111.076661.

100. Exley R, Clements MA, Hartung H, et al. $\alpha 6$-Containing nicotinic acetylcholine receptors dominate the nicotine control of dopamine neurotransmission in nucleus accumbens. Neuropsychopharmacology. 2007;33:2158-66. doi:10.1038/sj.npp. 1301617.

101. Drenan RM, Grady SR, Whiteaker P, et al. In vivo activation of midbrain dopamine neurons via sensitized, high-affinity $\alpha 6$ nicotinic acetylcholine receptors. Neuron. 2008;60:123-36. doi:10. 1016/j.neuron.2008.09.009.

102. Drenan RM, Grady SR, Steele AD, et al. Cholinergic modulation of locomotion and striatal dopamine release is mediated by $\alpha 6 \alpha 4^{*}$ nicotinic acetylcholine receptors. J Neurosci. 2010;30:9877-89. doi:10.1523/JNEUROSCI. 2056-10.2010.

103. Fowler $\mathrm{CD}, \mathrm{Lu} \mathrm{Q}$, Johnson PM, et al. Habenular $\alpha 5$ nicotinic receptor subunit signalling controls nicotine intake. Nature. 2011;471:597-601. doi:10.1038/nature09797.

104. Lotfipour S, Byun JS, Leach P, et al. Targeted deletion of the mouse $\alpha 2$ nicotinic acetylcholine receptor subunit gene (Chrna2) potentiates nicotine-modulated behaviors. J Neurosci. 2013;33: 7728-41. doi:10.1523/JNEUROSCI. 4731-12.2013.

105. Frahm S, Slimak MA, Ferrarese L, et al. Aversion to nicotine is regulated by the balanced activity of $\beta 4$ and $\alpha 5$ nicotinic receptor subunits in the medial habenula. Neuron. 2011;70:522-35. doi:10. 1016/j.neuron.2011.04.013.

106. Brunzell DH, McIntosh JM. Alpha7 nicotinic acetylcholine receptors modulate motivation to self-administer nicotine: implications 
for smoking and schizophrenia. Neuropsychopharmacology. 2012;37:1134-43. doi:10.1038/npp.2011.299.

107. Harenza JL, Muldoon PP, De Biasi M, et al. Genetic variation within the Chrna7 gene modulates nicotine reward-like phenotypes in mice. Genes Brain Behav. 2014;13:213-25. doi:10.1111/gbb.12113.

108. Grottick AJ, Trube G, Corrigall WA, et al. Evidence that nicotinic alpha(7) receptors are not involved in the hyperlocomotor and rewarding effects of nicotine. J Pharmacol Exp Ther. 2000;294:1112-9.

109. Markou A, Paterson NE. The nicotinic antagonist methyllycaconitine has differential effects on nicotine selfadministration and nicotine withdrawal in the rat. Nicotine Tob Res. 2001;3:361-73. doi:10.1080/14622200110073380.

110. Mogg AJ, Whiteaker P, McIntosh JM, et al. Methyllycaconitine is a potent antagonist of alpha-conotoxin-MII-sensitive presynaptic nicotinic acetylcholine receptors in rat striatum. J Pharmacol Exp Ther. 2002;302:197-204.

111. Besson M, David V, Baudonnat M, et al. Alpha7-nicotinic receptors modulate nicotine-induced reinforcement and extracellular dopamine outflow in the mesolimbic system in mice. Psychopharmacology. 2012;220:1-14. doi:10.1007/s00213011-2422-1.

112. Levin ED, Petro A, Rezvani AH, et al. Nicotinic alpha7- or beta2containing receptor knockout: effects on radial-arm maze learning and long-term nicotine consumption in mice. Behav Brain Res. 2009;196:207-13. doi:10.1016/j.bbr.2008.08.048.

113. Malin DH, Lake JR, Carter VA, et al. The nicotinic antagonist mecamylamine precipitates nicotine abstinence syndrome in the rat. Psychopharmacology. 1994;115:180-4.

114. Malin DH, Lake JR, Upchurch TP, et al. Nicotine abstinence syndrome precipitated by the competitive nicotinic antagonist dihydro-beta-erythroidine. Pharmacol Biochem Behav. 1998;60: 609-13.

115. Watkins SS, Stinus L, Koob GF, Markou A. Reward and somatic changes during precipitated nicotine withdrawal in rats: centrally and peripherally mediated effects. J Pharmacol Exp Ther. 2000;292:1053-64.

116. Damaj MI, Kao W, Martin BR. Characterization of spontaneous and precipitated nicotine withdrawal in the mouse. J Pharmacol Exp Ther. 2003;307:526-34. doi:10.1124/jpet.103.054908.

117. Salas R, Pieri F, De Biasi M. Decreased signs of nicotine withdrawal in mice null for the $\beta 4$ nicotinic acetylcholine receptor subunit. J Neurosci. 2004;24:10035-9. doi:10.1523/ JNEUROSCI. 1939-04.2004.

118. Jonkman S, Henry B, Semenova S, Markou A. Mild anxiogenic effects of nicotine withdrawal in mice. Eur J Pharmacol. 2005;516: 40-5. doi:10.1016/j.ejphar.2005.04.032.

119. Jackson KJ, Martin BR, Changeux JP, Damaj MI. Differential role of nicotinic acetylcholine receptor subunits in physical and affective nicotine withdrawal signs. J Pharmacol Exp Ther. 2008;325: 302-12. doi:10.1124/jpet.107.132977.

120. Epping-Jordan MP, Watkins SS, Koob GF, Markou A. Dramatic decreases in brain reward function during nicotine withdrawal. Nature. 1998;393:76-9. doi:10.1038/30001.

121. Johnson PM, Hollander JA, Kenny PJ. Decreased brain reward function during nicotine withdrawal in C57BL6 mice: evidence from intracranial self-stimulation (ICSS) studies. Pharmacol Biochem Behav. 2008;90:409-15. doi:10.1016/j.pbb.2008. 03.024.

122. Fowler CD, Tuesta L, Kenny PJ. Role of $\alpha 5^{*}$ nicotinic acetylcholine receptors in the effects of acute and chronic nicotine treatment on brain reward function in mice. Psychopharmacology. 2013;229:503-13. doi:10.1007/s00213-013-3235-1.

123. Igari M, Alexander JC, Ji Y, et al. Varenicline and cytisine diminish the dysphoric-like state associated with spontaneous nicotine withdrawal in rats. Neuropsychopharmacology. 2014;39:455-65. doi:10.1038/npp.2013.216.
124. Salas R, Main A, Gangitano D, De Biasi M. Decreased withdrawal symptoms but normal tolerance to nicotine in mice null for the alpha7 nicotinic acetylcholine receptor subunit. Neuropharmacology. 2007;53:863-9. doi:10.1016/j.neuropharm. 2007.08.017.

125. Stoker AK, Olivier B, Markou A. Role of $\alpha 7$ - and $\beta 4$-containing nicotinic acetylcholine receptors in the affective and somatic aspects of nicotine withdrawal: studies in knockout mice. Behav Genet. 2012;42:423-36. doi:10.1007/s10519-011-9511-0.

126. Franceschini D, Paylor R, Broide R, et al. Absence of alpha7containing neuronal nicotinic acetylcholine receptors does not prevent nicotine-induced seizures. Brain Res Mol Brain Res. 2002;98:29-40.

127. Jackson KJ, Sanjakdar SS, Muldoon PP, et al. The $\alpha 3 \beta 4^{*}$ nicotinic acetylcholine receptor subtype mediates nicotine reward and physical nicotine withdrawal signs independently of the $\alpha 5$ subunit in the mouse. Neuropharmacology. 2013;70:228-35. doi:10. 1016/j.neuropharm.2013.01.017.

128. Salas R, Sturm R, Boulter J, De Biasi M. Nicotinic receptors in the habenulo-interpeduncular system are necessary for nicotine withdrawal in mice. J Neurosci. 2009;29:3014-8. doi:10.1523/ JNEUROSCI. 4934-08.2009.

129. Picciotto MR, Brunzell DH, Caldarone BJ. Effect of nicotine and nicotinic receptors on anxiety and depression. Neuroreport. 2002;13:1097-106.

130. Turner JR, Castellano LM, Blendy JA. Nicotinic partial agonists varenicline and sazetidine-A have differential effects on affective behavior. J Pharmacol Exp Ther. 2010;334:665-72. doi:10.1124/ jpet.110.166280

131. Anderson SM, Brunzell DH. Low dose nicotine and antagonism of $\beta 2$ subunit containing nicotinic acetylcholine receptors have similar effects on affective behavior in mice. PLoS One. 2012;7: e48665. doi:10.1371/journal.pone.0048665.

132. Hussmann GP, DeDominicis KE, Turner JR, et al. Chronic sazetidine-A maintains anxiolytic effects and slower weight gain following chronic nicotine without maintaining increased density of nicotinic receptors in rodent brain. J Neurochem. 2014;129: 721-31. doi:10.1111/jnc.12653.

133. Yohn NL, Turner JR, Blendy JA. Activation of $\alpha 4 \beta 2 * / \alpha 6 \beta 2 *$ nicotinic receptors alleviates anxiety during nicotine withdrawal without upregulating nicotinic receptors. J Pharmacol Exp Ther. 2014;349:348-54. doi:10.1124/jpet.113.211706.

134. Ross SA, Wong JY, Clifford JJ, et al. Phenotypic characterization of an alpha 4 neuronal nicotinic acetylcholine receptor subunit knock-out mouse. J Neurosci. 2000;20:6431-41.

135. Labarca C, Schwarz J, Deshpande P, et al. Point mutant mice with hypersensitive alpha 4 nicotinic receptors show dopaminergic deficits and increased anxiety. Proc Natl Acad Sci U S A. 2001;98: 2786-91. doi:10.1073/pnas.041582598.

136. Buckley MJ, Surowy C, Meyer M, Curzon P. Mechanism of action of A-85380 in an animal model of depression. Prog Neuropsychopharmacol Biol Psychiatry. 2004;28:723-30. doi: 10.1016/j.pnpbp.2004.05.012.

137. Rollema H, Guanowsky V, Mineur YS, et al. Varenicline has antidepressant-like activity in the forced swim test and augments sertraline's effect. Eur J Pharmacol. 2009;605:114-6. doi:10. 1016/j.ejphar.2009.01.002.

138. Mineur YS, Eibl C, Young G, et al. Cytisine-based nicotinic partial agonists as novel antidepressant compounds. J Pharmacol Exp Ther. 2009;329:377-86. doi:10.1124/jpet.108.149609.

139. Andreasen J, Olsen G, Wiborg O, Redrobe J. Antidepressant-like effects of nicotinic acetylcholine receptor antagonists, but not agonists, in the mouse forced swim and mouse tail suspension tests. J Psychopharmacol. 2009;23:797-804. doi:10.1177/ 0269881108091587. 
140. Caldarone BJ, Wang D, Paterson NE, et al. Dissociation between duration of action in the forced swim test in mice and nicotinic acetylcholine receptor occupancy with sazetidine, varenicline, and 5-I-A85380. Psychopharmacology. 2011;217:199-210. doi:10. 1007/s00213-011-2271-y.

141. Caldarone BJ, Harrist A, Cleary MA, et al. High-affinity nicotinic acetylcholine receptors are required for antidepressant effects of amitriptyline on behavior and hippocampal cell proliferation. Biol Psychiatry. 2004;56:657-64. doi:10.1016/j.biopsych.2004.08.010.

142. Rabenstein RL, Caldarone BJ, Picciotto MR. The nicotinic antagonist mecamylamine has antidepressant-like effects in wild-type but not beta2- or alpha7-nicotinic acetylcholine receptor subunit knockout mice. Psychopharmacology. 2006;189:395-401. doi:10. 1007/s00213-006-0568-z.

143. Salas R, Pieri F, Fung B, et al. Altered anxiety-related responses in mutant mice lacking the beta4 subunit of the nicotinic receptor. J Neurosci. 2003;23:6255-63.

144. Booker TK, Butt CM, Wehner JM, et al. Decreased anxiety-like behavior in beta3 nicotinic receptor subunit knockout mice. Pharmacol Biochem Behav. 2007;87:146-57. doi:10.1016/j.pbb. 2007.04.011.
145. Semenova S, Contet C, Roberts AJ, Markou A. Mice lacking the $\beta 4$ subunit of the nicotinic acetylcholine receptor show memory deficits, altered anxiety- and depression-like behavior, and diminished nicotine-induced analgesia. Nicotine Tob Res. 2012;14: 1346-55. doi:10.1093/ntr/nts107.

146. Tucci SA, Genn RF, File SE. Methyllycaconitine (MLA) blocks the nicotine evoked anxiogenic effect and 5-HT release in the dorsal hippocampus: possible role of $\alpha 7$ receptors. Neuropharmacology. 2003;44:367-73. doi:10.1016/S0028-3908(02)00391-X.

147. Pandya AA, Yakel JL. Activation of the $\alpha 7$ nicotinic ACh receptor induces anxiogenic effects in rats which is blocked by a $5-\mathrm{HT}_{1} \mathrm{a}$ receptor antagonist. Neuropharmacology. 2013;70:35-42. doi:10. 1016/j.neuropharm.2013.01.004.

148. Fiore MC, Jaén CR, Baker TB, et al. Treating tobacco use and dependence: 2008 update U.S. Public Health Service Clinical Practice Guideline executive summary. Respir Care. 2008;53: 1217-22.

149. Jackson KJ, Kota DH, Martin BR, Damaj MI. The role of various nicotinic receptor subunits and factors influencing nicotine conditioned place aversion. Neuropharmacology. 2009;56:970-4. doi: 10.1016/j.neuropharm.2009.01.023. 